\title{
Utilization of Agro-Industrial Residues and Municipal Waste of Plant Origin for Cellulosic Ethanol Production
}

\author{
Fabiano Avelino Gonçalves ${ }^{1,3}$, Eliana Janet Sanjinez-Argandoña ${ }^{2}$, Gustavo Graciano Fonseca ${ }^{*}$ \\ ${ }^{1}$ Laboratory of Bioengineering, Faculty of Engineering, Federal University of Grande Dourados, Dourados, Brazil; ${ }^{2}$ Laboratory of \\ Food Technology, Faculty of Engineering, Federal University of Grande Dourados, Dourados, Brazil; ${ }^{3}$ Laboratory of Chemical En- \\ gineering, Faculty of Engineering, Federal University of Rio Grande do Norte, Natal, Brazil. \\ E-mail: "ggf@ufgd.edu.br
}

Received September $3^{\text {rd }}, 2011$; revised October $5^{\text {th }}$, 2011; accepted November $6^{\text {th }}, 2011$.

\begin{abstract}
Today's search for alternative sources of energy to reduce the use of fossil fuels is motivated by environmental, socioeconomic and political reasons. The use of agro-industrial and municipal wastes of plant origin for ethanol production appears to be the best option to solve the dilemma of using food sources to produce biofuels, since it adds value to these wastes in eco-efficient processes. This paper highlights the potential of agro-industrial and municipal wastes for cellulosic ethanol production.
\end{abstract}

Keywords: Bioethanol, Agro-Industrial Byproducts, Environmental Preservation, Eco-Efficiency

\section{Introduction}

The interest in alternative sources of energy from plant biomass to replace the dwindling reserves of fossil fuel and petroleum derivatives has been influenced by the constant increase in world crude oil prices. This was evidenced as recently as early 2011, when uncertainties in the political situation of some countries in the Middle East and North Africa drove the price of crude oil to over US\$ 120 per barrel on the London Stock Exchange [1]. Moreover, the combustion of petrochemical fuels has influenced climate change and aggravated global warming, mainly due the emission of greenhouse gases (GHG). Attempts to mitigate environmental impacts have led to the search for renewable and clean sources of energy. These sources include sugarcane ethanol and corn starch ethanol, which represent alternatives to overcome economic problems and environmental impacts.

However, in some countries, the sharp increase in the production of ethanol from starch may lead to controversies regarding the use of this raw material for biofuel or food production, not to mention the high demand for tillable land and agricultural inputs [2]. In this context, an alternative to starch and sucrose-based biofuels has been the production of ethanol from plant biomass (cellulosic ethanol) derived from agro-industrial wastes [2-5] and mu- nicipal waste [2,6-10]. The conversion of cellulose into fermentable sugars for ethanol production is a promising alternative to meet the global demand for biofuels.

This paper offers a review of the available sources of plant biomass used for the production of cellulosic ethanol, and the environmental, socioeconomic and political policies involved in cellulosic ethanol production.

\section{Plant Biomass}

Plant biomass, the most abundant source of organic matter on earth, is biodegradable and renewable [5]. This biomass is found in forests, agro-industrial residues and municipal waste [11], and is a potential source of material for the production of ethanol [2], which can replace gasoline due to its high energy efficiency [5].

The structure of plant cell walls consists of polysaccharides, proteins, phenolic compounds and minerals. Polysaccharides, which represent about $90 \%$ of the dry weight of the cell wall, consist of cellulose (20\% - 40\%), hemicellulose $(15 \%-25 \%)$ and pectin $(30 \%)$, while lignin, a non-polysaccharide, gives the cell wall its rigidity [12].

Cellulose, the main constituent of plants [13], is a linear homopolysaccharide with 8000 - 12000 glucose units linked by 1,4-beta-glycosidic bonds. Hemicellulose is a complex heteropolysaccharide composed of glucose, ga- 
lactose, mannose, xylose, arabinose, uronic acids and acetyl groups. The branched chain presents a degree of polymerization of less than 200 units [14]. Pectin is a complex heteropolysaccharide constituted of axial connections of $\alpha-1,4-\mathrm{D}$-galacturonic acid units composed of ramose, arabinose and galactose [15]. Lignin is a phenollic polymer that contributes to the structural rigidity of plant tissues [12]. It is composed of macromolecules synthesized by radicals from three $p$-hydroxycinnamic precursor alcohols: $p$-coumaryl, coniferyl and sinapyl [14].

Glucose molecules are joined by glycosidic bonds to form linear chains (cellulose) that interact with each other through hydrogen bonds, forming a structure of elementary fibrils that are water-insoluble and highly crystalline. Four elementary fibrils are grouped in a hemicellulose monolayer, surrounded by a hemicellulose and lignin matrix, called cellulose microfibrils [14,16, 17].

Lignocellulosic material is a generic term that describes the main constituents of plants, i.e., cellulose, hemicellulose and lignin [18], as indicated in Figure 1. Its composition depends not only on the type of plant (Table 1), but also on the selected part of the plant [19], and on growth conditions $[20,21]$. This material differs from products with high sugar and starch content [5,22-24].

\section{Global Scenario}

Global ethanol production is monopolized by two major producers, the USA, which uses corn starch, and Brazil, which uses sugarcane sucrose [25]. In both cases, this production is based on food sources. According to Pimentel et al. [26], the allocation of food sources for the production of biofuels reaches a critical point when an impasse is reached between the production of raw material for fuel ethanol or for food. This impasse represents a bottleneck in the maintenance and expansion of the biofuels market. One of the short-term alternatives would be to use these plants solely for food and use only their lignocellulosic materials for the production of ethanol. This would help mitigate environmental pollution and mini- mize the use of food sources for ethanol production [10].

Based on this idea, the Chinese government encourages the production of ethanol only from non-food substrates, e.g., perennial grasses, and plant husks and chaff [27], and strictly controls the territorial expansion of food substrates used in ethanol production [28]. Currently, China

Table 1. Cellulose, hemicellulose and lignin contents of some agro-industrial and urban residues of plant origin.

\begin{tabular}{|c|c|c|c|}
\hline \multirow{2}{*}{ Plant biomass } & \multicolumn{3}{|c|}{ Compound (\%) } \\
\hline & Cellulose & Hemicellulose & Lignin \\
\hline Sugarcane bagasse & 33 & 30 & 29 \\
\hline Wheat straw & 30 & 24 & 18 \\
\hline Sorghum straw & 33 & 18 & 15 \\
\hline Rice straw & 32 & 24 & 13 \\
\hline Oat straw & 41 & 16 & 11 \\
\hline Maize ear & 42 & 39 & 14 \\
\hline Maize stalk & 35 & 15 & 19 \\
\hline Barley straw & 40 & 20 & 15 \\
\hline Alfalfa stalk & 48.5 & 6.5 & 16.6 \\
\hline Rice husk & 36 & 15 & 19 \\
\hline Eucalyptus grandis & 38 & 13 & 37 \\
\hline Eucalyptus saligna & 45 & 12 & 25 \\
\hline Pinus sp. & 44 & 26 & 29 \\
\hline Journal & 61 & 16 & 21 \\
\hline Processed paper & 47 & 25 & 12 \\
\hline Angiosperm wood & $40-50$ & $24-40$ & $18-25$ \\
\hline Gymnosperm wood & $45-50$ & $25-35$ & $20-30$ \\
\hline Nuts husk & $25-30$ & $25-30$ & $30-40$ \\
\hline White paper & 85 - 99 & 0 & $0-15$ \\
\hline Grasses & $25-40$ & $35-50$ & $19-25$ \\
\hline Leafs & $15-20$ & $80-85$ & 0 \\
\hline Cottonseed lint & $80-90$ & $0-15$ & 0 \\
\hline
\end{tabular}

Source: [29-34].
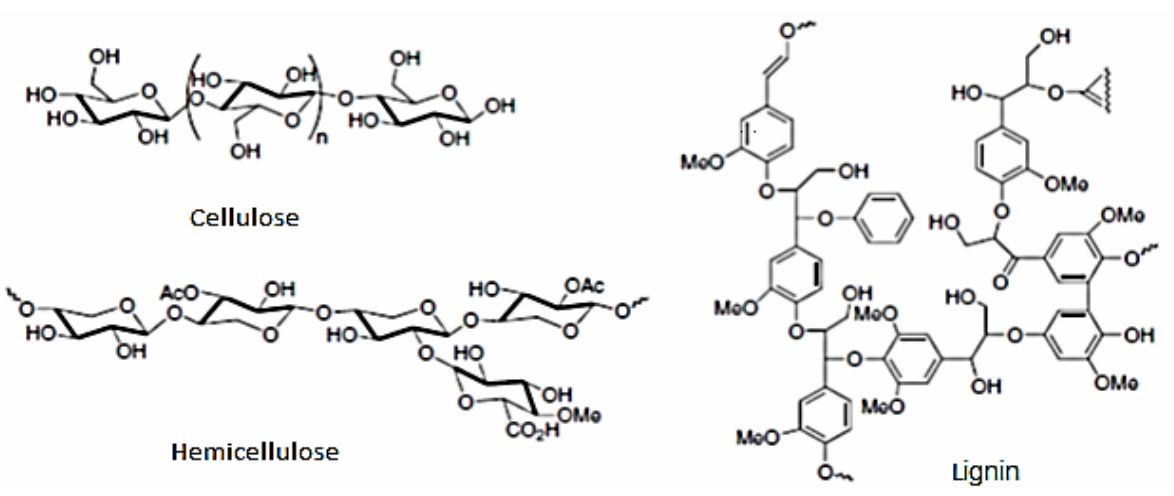

Figure 1. Structural chains of lignocellulosic materials. 
is the world's largest rice and wheat producer. The country generates huge amounts of agro-industrial residues, which may be used alternatively for ethanol production instead of impacting the environment $[35,36]$.

Brazil's sugarcane production seeks to meet domestic and export market demands for ethanol and sugar. However, this economic dependence has serious negative consequences for the population. In early 2011, there was a shortage of ethanol as a result of the higher demand for sucrose for sugar production (due to rising sugar export prices), allied to the sugarcane off-season, which resulted in an average price increase of $20.5 \%$.

Another prospect is ethanol production in Brazil driven by the incorporation of sugarcane bagasse ethanol produced at the same industrial plant, resulting in lower production costs. This proposal would increase the availability of ethanol during the sugarcane off-season, and represent higher economic and ecological efficiencies in the process. This concept is strengthened by data from Brazil's 2010/2011 sugarcane harvest. Although it was a bumper crop, it did not suffice to meet the demand for ethanol and sugar production. In the 2011 season, Brazil's sugarcane production volume will fall short of industrial demand by $23 \%$. This volume is expected to be approximately 632 million tons, while the volume needed to meet current domestic and export demand is 775.6 million tons. The projections for 2020 are that Brazil's sugarcane production will fall $34 \%$ below demand, with an estimated supply of 974 million tons to meet a demand exceeding 1.3 billion tons [37].

All around the world, new alternatives are being investigated for the production of cellulosic ethanol based on crops as the source of raw materials. These alternatives include eucalyptus (Eucalyptus sp.) and leucaena (Leucaena sp.) as well as fast-growing grasses of high productivity, e.g., elephant-grass (Pennisetum purpureum), used as forage in South America, switchgrass (Panicum virgatum), a species native to North America, and tall grass of the genus Miscanthus, which is of greater interest in Europe [38]. Although cultivated plant biomass represents an advance in cellulosic ethanol production, agro-industrial residues and municipal waste of plant origin are priorities for use as substrates for cellulosic ethanol production [30,39-43].

\section{Socioenvironmental, Economic and Political Policies}

Changes in the global energy matrix have been driven by fuels derived from animal, plant and microbial organic matter. The search for cheaper fuels in developing countries has fostered a growth in the economic activity of biofuel production, facilitated by the fact that most of these countries have large tracts of land, available water supplies and favorable weather conditions, which may lead to regional development (employment and income generation, population devolution and an increase in foreign exchange reserves). However, it is important to underline the need for strategic agricultural zoning studies to avoid environmental and socioeconomic disasters promoted by huge green deserts, as well as the use of biofuels as an extra energy supply and not merely to replace non-renewable sources of energy.

Renewable sources of energy are desirable because they represent a safe and sustainable energy supply, and lower GHG emissions [3,44]. Ethanol production using lignocellulosic biomass is one of the most important technologies for an ecologically feasible [45] and sustainable production of renewable fuels [44,46-48] to minimize the environmental impact caused by GHG. The six main GHGs are carbon dioxide, methane, nitrous oxide, hydrofluorocarbons, perfluorocarbons and sulfur hexafluoride [49]. The carbon dioxide produced by burning biofuels is partially recycled in the process of photosynthesis, which is when plant biomass is formed [50,51]. Ethanol has a positive carbon balance [52], and also releases low amounts of nitrous oxide and sulfur dioxide during combustion [53].

The use of municipal waste of plant origin as a substrate for ethanol production can lead to a temporary increase in organic compounds and toxic substances in the environment [54]. However, this amount is small when compared to that produced by liquid fossil fuels [55]. According to the Intergovernmental Panel on Climate Change [49], climate change is caused by the excessive increase of GHGs in the atmosphere, intensified by human activities, which is the case of fossil fuels that have been in use since the pre-industrial age. Significant amounts of carbon dioxide are released into the atmosphere annually. In 2002, about 24 billion metric tons of carbon dioxide would be produced by burning fossil fuels. This number is estimated to reach 33 billion by 2015 [51].

Studies on biofuel by Sukimaran et al. [56] demonstrated that the potential of ethanol is comparable to that of petroleum, making it economically feasible for commercial purposes. Moreover, these authors emphasize that the octane rating of ethanol is higher than that of gasoline and that it produces lower air pollutant emissions. In the 1990s, the Tennessee Valley Authority (USA) developed an efficient technology for converting vegetable waste into ethanol [57]. The material was composed of $45 \%$ glucose and 9\% hemicellulose [2,58,59] and allowed for the production of cellulosic ethanol. According to Shi et al. [9], the use of municipal waste of plant origin for ethanol production is a promising strategy to supply the world's energy needs and reduce GHG emissions. Their estimates of the socioeconomic development of 
173 countries point to a global production of 82.9 billion liters of ethanol from municipal waste, replacing the consumption of $5.36 \%$ of gasoline.

In a comparison of the eco-efficiency of liquid fuels, i.e., gasoline, corn starch ethanol and cellulosic ethanol, Hill et al. [55] found that cellulosic ethanol is the most eco-efficient. These authors reported the following costs to produce 1 billion gallons of fuel: gasoline-US\$ 416 million, corn starch ethanol-US\$ 614 million, and cellulosic ethanol_US\$ 208 million. Figure 2 indicates the time required to eliminate $\mathrm{CO}_{2}$ emissions produced by deforestation, harvesting and production of some biofuels. These findings emphasize the importance of producing cellulosic ethanol, which not only adds value to plant biomass for biofuel production but also requires no expansion of farmland.

The International Energy Agency's projections for the global biofuel demand reveal a drastic growth in the com- ing decades, with a strong contribution from the road transport sector up to 2030 [60]. The growing use of biofuels is influenced mainly by the Montreal (1987), Kyoto (1997) and Copenhagen (2009) Protocols. However, the UN Climate Change Conference (COP-16) held in Mexico in 2010 pointed to uncertainties for the second phase of the Kyoto Protocol, which sets mandatory and voluntary targets for the reduction of global emission caps (GEC) in industrialized countries. Nevertheless, there is a tendency for a period without mandatory targets for environmental preservation from 2012. The increase in biofuel consumption is influenced by voluntary and mandatory targets adopted by some countries (Table 2). According to the World Energy Assessment [61] and Goldenberg [62], projections for the world energy scenario up to 2100 are optimistic, with an increase in renewable sources and the consequent reduction of non-renewable sources [61].

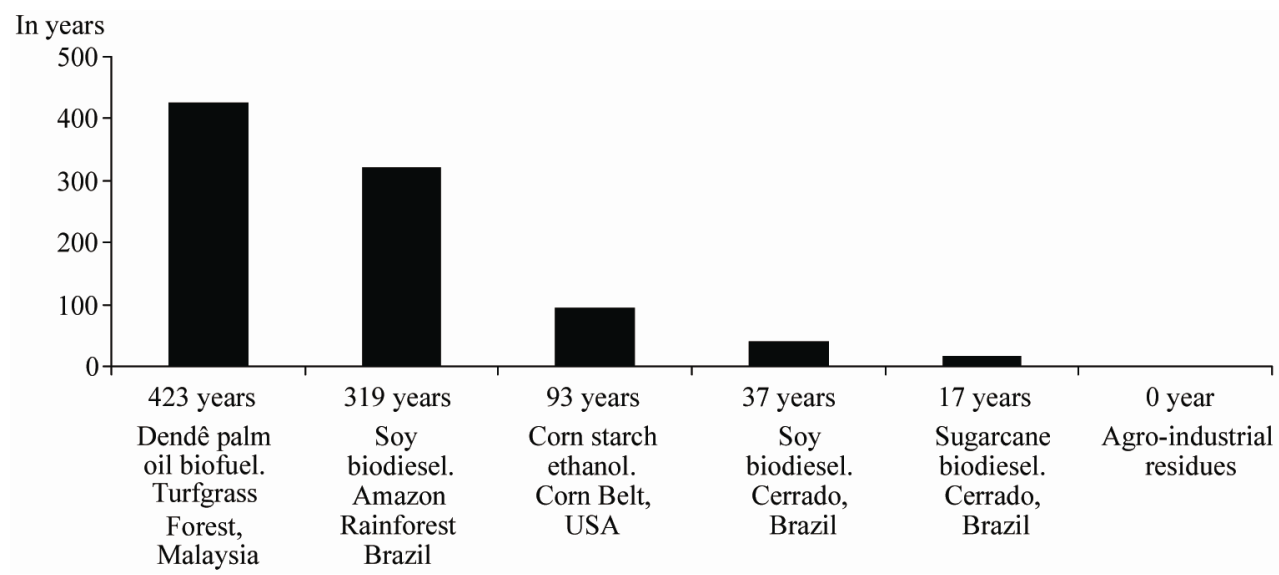

Figure 2. Time required to eliminate carbon dioxide emissions caused by deforestation, harvesting and production of some biofuels [63].

Table 2. Voluntary and mandatory biofuel targets of some countries.

\begin{tabular}{|c|c|c|}
\hline Country & Target & Condition \\
\hline Germany & Addition of $6.75 \%$ of anhydrous ethanol to gasoline in 2010; increase to 8\% in 2015 and 10\% in 2020. & Mandatory \\
\hline Brazil & $\begin{array}{l}\text { Mixture of } 20 \% \text { to } 25 \% \text { of anhydrous ethanol in gasoline and } 5 \% \text { of biodiesel in diesel in 2010; expan- } \\
\text { sion of the use of hydrated ethanol. }\end{array}$ & Mandatory \\
\hline Canada & Addition of 5\% of anhydrous ethanol in gasoline in 2010; addition of 2\% of biodiesel in diesel in 2012. & Mandatory \\
\hline China & Utilization of $15 \%$ of biofuels in the transport sector. & Voluntary \\
\hline France & Addition of $7 \%$ of anhydrous ethanol in gasoline in $2010^{\mathrm{a}}$ and increase to $10 \%$ in $2015^{\mathrm{b}}$. & ${ }^{\mathrm{a}}$ Voluntary and ${ }^{\mathrm{b}}$ mandatory \\
\hline Italy & Addition of $5.75 \%$ of anhydrous ethanol in gasoline in 2010 and increase to $10 \%$ in 2010 . & Mandatory \\
\hline European Union & Utilization of $10 \%$ of biofuels in 2010 . & Mandatory \\
\hline
\end{tabular}

Source: [64]. 


\section{Final Remarks}

The environmental changes influenced by greenhouse gas emissions and global warming, the rising prices of crude oil and its derivatives, and the ever growing global demand for fuels, have led to the development of numerous biotechnological processes to minimize the use of fossil fuels in the late $20^{\text {th }}$ and early $21^{\text {st }}$ centuries

These innovations include the development of biofuels, such as ethanol, which started in Brazil in 1920 and was strongly boosted by Brazil's Pro-Alcohol Program established in 1975. Since then, ethanol participates effectively in Brazil's energy matrix and is one of the cleanest technologies in the world. Population growth, an expanding agribusiness sector and the search for sustainable development have resulted in the eco-efficient production of cellulosic ethanol from low-cost agro-industrial residues and municipal waste of plant origin.

\section{Acknowledgements}

The authors gratefully acknowledge the Brazilian research funding agencies CNPq and FUNDECT for their financial support.

\section{REFERENCES}

[1] London Stock Exchange, “Oilb Etfs Oil Securities ld Etfs Brent Oil,” 2011.

http://www.londonstockexchange.com/exchange/prices-a nd-markets/ETCs/company-summary.html?fourWayKey $=$ GB00B0CTWC01JEUSDETCS

[2] S. Prasad, A. Singh and H. C. Joshi, "Ethanol as an Alternative Fuel from Agricultural, Industrial and Urban Residues," Resources, Conservation and Recycling, Vol. 50, 2007, pp. 1-39. doi:10.1016/j.resconrec.2006.05.007

[3] Y. Sun and J. Cheng, "Hydrolysis of Lignocellulosic Materials for Ethanol Production: A Review,” Bioresource Technology, Vol. 83, No. 1, 2002, pp. 1-11. doi:10.1016/S0960-8524(01)00212-7

[4] A. Abril, "Etanol Aditivo o Alternativa Para el Combustible Automotor,” I Taller Nacional de Etanol Celulósico, ICIDCA, Habana, 2008.

[5] D. Abril and A. Abril, "Ethanol from Lignocellulosic Biomass," Ciencia e Investigación Agrária, Vol. 36, No. 2, 2009, pp. 177-190.

doi:10.4067/S0718-16202009000200003

[6] B. C. Qi, C. Aldrich, L. Lorenzen and G. W. Wolfaardt, "Acidogenic Fermentation of Lignocellulosic Substrate with Activated Sludge," Chemical Engineering Communications, Vol. 192, No. 9, 2005, pp. 1221-1242. doi:10.1080/009864490515676

[7] A. Roig, M. L. Cayuela and M. A. Sánchez-Monedero, "An Overview on Olive Mill Wastes and Their Valorization Methods,” Waste Management, Vol. 26, No. 9, 2006, pp. 960-969. doi:10.1016/j.wasman.2005.07.024

[8] G. Rodríguez, A. Lama, R. Rodríguez, A. Jiménez, R.
Guilléna and J. Fernández-Bolaños, "Olive Stone an Attractive Source of Bioactive and Valuable Compounds," Bioresource Technology, Vol. 99, No. 13, 2008, pp. 52615269. doi:10.1016/j.biortech.2007.11.027

[9] A. Z. Shi, L. P. Koh and H. T. W. Tan, "The Biofuel Potential of Municipal Solid Waste,” Global Change Biology Bioenergy, Vol. 1, No. 5, 2009, pp. 317-320. doi:10.1111/j.1757-1707.2009.01024.X

[10] M. F. Demirbas, M. Balat and H. Balat, "Biowastes-toBiofuels,” Energy Conversion and Management, Vol. 52, No. 4, 2011, pp. 1815-1828. doi:10.1016/j.enconman.2010.10.041

[11] E. Billa, B. Monties and C. Choudens, "Silica and Phenolic Acid Derivatives in Wheat Straw and Corresponding High Yield Pulps,” Conference Proceedings: Straw-A Valuable Raw Material, Cirencester, 1993, pp. 20-22.

[12] M. S. Buckeridge, G. B. Silva and A. A. Cavalari, “Parede Celular,” In: G. B. Kerbauy, Ed., Fisiologia Vegetal, Guanabara Koogan, Rio de Janeiro, 2008, pp. 165-181.

[13] R. Wightman and S. Turner, "Trafficking of the Plant Cellulose Synthase Complex,” Plant Physiology, Vol. 153, No. 2, 2010, pp. 427-432. doi:10.1104/pp.110.154666

[14] D. Fengel and G. Wegener, "Wood Chemistry, Ultrastructure and Reactions,” 1st Edition, Walter de Gruyter, Berlin, 1989.

[15] R. P. de Vries and J. Visser, “Aspergillus Enzymes Involved in Degradation of Plant Cell Wall Polysaccharides," Microbiology Molecular Biology Reviews, Vol. 65, No. 4, 2001, pp. 497-522.

doi:10.1128/MMBR.65.4.497-522.2001

[16] M. Matulova, R. Nouaille, P. Capek, M. Péan, E. Forano and A. M. Delort, "Degradation of Wheat Straw by Fibrobacter Succinogenes S85: a Liquid- and Solid-State Nuclear Magnetic Resonance Study," Applied and Environmental Microbiology, Vol. 71, No. 3, 2005, pp. 1247-1253. doi:10.1128/AEM.71.3.1247-1253.2005

[17] C. E. Wyman, S. R. Decker, M. E. Himmel, J. W. Brady, C. E. Skopec and L. Viikari, "Polysaccharides: Structural Diversity and Functional Versatility,” S. Dumitriu, Ed., Dekker, New York, 2005, pp. 995-1033.

[18] D. L. Klass, "Biomass for Renewable Energy, Fuels and Chemicals,” 1st Edition, Academic Press, San Diego, 1998.

[19] R. M. Brown Jr., "Cellulose Structure and Biosynthesis," Pure and Applied Chemistry, Vol. 71, No. 5, 1999, pp. 767-775. doi:10.1351/pac199971050767

[20] B. Barl, C. G. Biliaderis, D. M. Murray and A. W. Macgregor, "Combined Chemical and Enzymatic Treatments of Corn Husk Lignocellulosics," Journal Science Food and Agriculture, Vol. 56, No. 2, 1991, pp. 195-214. doi:10.1002/jsfa.2740560209

[21] A. Wiselogel, J. Tyson and D. Johnsson, "Biomass FeedStock Resources and Composition,” In: C. E. Wyman, Ed., Handbook on Bioethanol: Production and Utilization, Taylor and Francis, Washington DC, 1996, p. 105.

[22] M. Galbe and G. Zacchi, "Simulation Processes for Conversion of Lignocelluloses,” In: J. N. Saddler, Ed., Bioconversion of Forest and Agricultural Plant Residues, 
CAB International, Wallinford, 1993, pp. 291-319.

[23] M. Galbe, M. Larsson, K. Stemberg, C. Tenborg and G. Zacchi, "Ethanol from Wood: Design and Operation of a Process Development Unit for Technoeconomic Process Evaluation,” ACS Symposium Series 666, American Chemical Society, Washington DC, 1997, pp. 110-129.

[24] J. D. McMillan, "Bioethanol Production: Status and Prospects,” Renewable Energy, Vol. 10, No. 2-3, 1997, pp. 295-302. doi:10.1016/0960-1481(96)00081-X

[25] B. Hahn-Hägerdal, M. Galbe, M. F. Gorwa-Grauslund, G. Lidén and G. Zacchi, "Bio-Ethanol: The Fuel of Tomorrow from the residues of Today," Trends in Biotechnology, Vol. 24, No. 12, 2006, pp. 449-556. doi:10.1016/j.tibtech.2006.10.004

[26] D. Pimentel, A. Marklein, M. A. Toth, M. Karpoff, G. S. Paul and R. McCormack, "Food versus Biofuels: Environmental and Economic Costs,” Human Ecology, Vol. 37, 2009, pp. 1-12. doi:10.1007/s10745-009-9215-8

[27] S. Z. Li and C. Chan-Halbrendt, "Ethanol Production in (the) People's Republic of China: Potential and Technologies,” Applied Energy, Vol. 86, No. 1, 2009, pp. 162-169. doi:10.1016/j.apenergy.2009.04.047

[28] X. Fang, Y. Shen, J. Zhao, X. Bao and Y. Qu, "Status and Prospect of Lignocellulosic Bioethanol Production in China,” Bioresource Technology, Vol. 101, No. 13, 2010, pp. 4814-4819. doi:10.1016/j.biortech.2009.11.050

[29] R. C. Kuhad and A. Singh, "Lignocellulose Biotechnology: Current and Future Prospects," Critical Reviews in Biotechnology, Vol. 13, No. 2, 1993, pp. 151-172. doi:10.3109/07388559309040630

[30] R. Shleser, "Ethanol Production in Hawaii, Processes, Feedstocks, and Current Economic Feasibility of Fuel Grade Ethanol Production in Hawaii," State of Hawaii, Department of Business, Economic Development and Tourism, Honolulu, 1994.

[31] L. Olsson and B. Hahn-Hägerdal, "Fermentation of Lignocellulosic Hydrolysates for Ethanol Production,” Enzyme and Microbial Technology, Vol. 18, No. 5, 1996, pp. 312-331. doi:10.1016/0141-0229(95)00157-3

[32] S. W. Cheung and B. C. Anderson, "Laboratory Investigation of Ethanol Production from Municipal Primary Waste,” Bioresource Technology, Vol. 59, No. 1, 1997, pp. 81-96. doi:10.1016/S0960-8524(96)00109-5

[33] R. Boopathy, "Biological Treatment of Swine Waste Using Anaerobic Baffled Reactors,” Bioresource Technology, Vol. 64, No. 1, 1998, pp. 1-6. doi:10.1016/S0960-8524(97)00178-8

[34] T. Dewes and E. Hunsche, "Composition and Microbial Degradability in the Soil of Farmyard Manure from Ecologically-Managed Farms," Biological Agriculture and Horticulture, Vol. 16, No. 3, 1998, pp. 251-268.

[35] B. Yang and Y. Lu, "The Promise of Cellulosic Ethanol Production in China," Journal of Chemical Technology and Biotechnology, Vol. 82, No. 1, 2007, pp. 6-10. doi:10.1002/jctb.1637

[36] X. Fang, S. Yano, H. Inoue and S. Sawayama, "Strain
Improvement of Acremonium Cellulolyticus for Cellulase Production by Mutation,” Journal of Bioscience and Bioengineering, Vol. 107, No. 3, 2009, pp. 256-261. doi:10.1016/j.jbiosc.2008.11.022

[37] Diário Comércio, Indústria e Serviços, "Safra da Cana Será Menor Que Demanda Das Usinas,” 2011.

http://www.dci.com.br/noticia.asp?id_editoria=7\&id_noti cia $=368562 \&$ editoria $=$

[38] Banco Nacional de Desenvolvimento Econômico e Social, "Bioetanol de Cana-de-Açúcar: Energia Para o Desenvolvimento Sustentável,” BNDES e CGEE, Rio de Janeiro: 2008.

[39] M. P. Austin and M. J. Gaywood, "Current Problems of Environmental Gradients and Species Response Curves in Relation to Continuum Theory," Journal of Vegetation Science, Vol. 5, No. 4, 1994, pp. 473-482. doi:10.2307/3235973

[40] R. G. Koegel and R. J. Straub, "Fractionation of Alfalfa for Food, Feed, Biomass and Enzymes," American Society of Agricultural Engineers, Vol. 39, No. 3, 1996, pp. 769-774.

[41] R. J. Bothast and B. C. Saha, "Ethanol Production from Agricultural Biomass Substrates," Advances in Applied Microbiology, Vol. 44, 1997, pp. 261-286. doi:10.1016/S0065-2164(08)70464-7

[42] S. K. Sharma, K. L. Kalra and H. S. Grewal, "Fermentation of Enzymatically Saccharified Sunflower Stalks for Ethanol Production and Its Scale up,” Bioresource Technology, Vol. 85, No. 1, 2002, pp. 31-33. doi:10.1016/S0960-8524(02)00076-7

[43] K. L. Kadam and J. D. McMillan, "Availability of Corn Stover as a Sustainable Feedstock for Bioethanol Production,” Bioresource Technology, Vol. 88, No. 1, 2003, pp. 17-23. doi:10.1016/S0960-8524(02)00269-9

[44] A. Demirbas, "Bioethanol from Cellulosic Materials: A Renewable Motor Fuel from Biomass,” Energy Sources, Vol. 21, 2005, pp. 327-337. doi:10.1080/00908310390266643

[45] M. S. Buckeridge, "Rotas Para o Etanol Celulósico em um Cenário de Mudanças Climáticas,” Opiniões, Ribeirão Preto, 2008, pp. 62-64.

[46] C. E. Wyman, "Handbook on Bioethanol: Production and Utilization,” Taylor and Francis, Washington DC, 1996.

[47] J. Pitkanen, A. Aristidou, L. Salusjarvi, L. Ruohonen and M. Penttila, "Metabolic Flux Analysis of Xylose Metabolism in Recombinant Saccharomyces Cerevisiae Using Continuous Culture," Metabolic Engineering, Vol. 5, No. 1, 2003, pp. 16-31. doi:10.1016/S1096-7176(02)00012-5

[48] D. J. Schell, C. J. Riley, N. Dowe, J. Farmer, K. N. Ibsen, M. F. Ruth, S. T. Toon and R. E. Lumpkin, "A Bioethanol Process Development Unit: Initial Operating Experiences and Results with Corn Fiber Feedstock,” Bioresource Technology, Vol. 91, No. 2, 2004, pp. 179-188. doi:10.1016/S0960-8524(03)00167-6

[49] Intergovernmental Panel on Climate Change, "Fourth Assessment Report: Summary for Policymakers,” 2005.

[50] Y. Lin and S. Tanaka, "Ethanol Fermentation from Bio- 
mass Resources: Current State and Prospects,” Applied Microbiology and Biotechnology, Vol. 69, No. 6, 2006, pp. 627-642. doi:10.1007/s00253-005-0229-X

[51] J. Shreeve, "Redesigning Life to Make Ethanol," Technology Review, Vol. 109, No. 3, 2006, pp. 66-68.

[52] J. D. Broder, J. W. Barrier and G. R. Lightsey, "Conversion of Cotton Trash and Other Residues to Liquid Fuel," In: J. S. Cundiff, Ed., Liquid Fuel from Renewable Resources, Proceedings of an Alternative Energy Conference Held in Nashville, St. Joseph, American Society of Agricultural Engineers, 1992, pp. 12-15, 198-200.

[53] P. A. M. Claassen, J. B. van Lier, C. A. M. López, E. W. J. van Niel, L. Sijtsma, A. J. M. Stams, S. S. de Vries and R. A. Weusthuis, "Utilisation of Biomass for the Supply of Energy Carriers,” Applied Microbiology and Biotechnology, Vol. 52, No. 6, 1999, pp. 741-755. doi:10.1007/s002530051586

[54] C. Cardona, O. Sánchez, J. Ramírez and L. Álzate, "Biodegradación de Residuos Orgánicos de Plazas de Mercado,” Revista Colombiana de Biotecnología, Vol. 6, No. 2, 2004, pp. 78-89.

[55] J. Hill, S. Polasky, E. Nelson, D. Tilman, H. Huo, L. Ludwig, J. Neumann, H. Zheng and D. Bonta, "Climate Change and Health Costs of Air Emissions from Biofuels and Gasoline," Sustainability Science, Vol. 106, No. 6, 2009, pp. 2077-2082. doi:10.1073/pnas.0812835106

[56] R. K. Sukumaran, R. R. Singhania, G. M. Mathew and A. Pandey, "Cellulase Production Using Biomass Feed Stock and Its Application in Lignocellulose Saccharification for Bio-Ethanol Production,” Renewable Energy, Vol. 34, No. 2, 2009, pp. 421-424. doi:10.1016/j.renene.2008.05.008
[57] R. O. Lambert, M. R. Moore-Bulls Jr. and J. W. Barrier, "An Evaluation of Two Acid Hydrolysis Processes for the Conversion of Cellulosic Feedstocks to Ethanol and Other Chemicals," Applied Biochemistry and Biotechnology, Vol. 24-25, 1990, pp. 773-783. doi:10.1007/BF02920294

[58] C. E. Wyman and B. J. Goodman, "Biotechnology for Production of Fuel, Chemicals and Materials from Biomass," Applied Biochemistry and Biotechnology, Vol. 39-40, No. 1, 1993, pp. 41-59. doi:10.1007/BF02918976

[59] C. E. Wyman, "Ethanol from Lignocellulosic Biomass: Technology, Economics and Opportunities,” Bioresource Technology, Vol. 50, No x, 1994, pp. 3-16. doi:10.1016/0960-8524(94)90214-3

[60] International Energy Agency, "The International Energy Agency, supporting the Gleneagles Plan of Action," Support of the G8 Plan of Action, Hokkaido, 2008.

[61] World Energy Assessment. "Energy and the Challenge of Sustainability,” United Nations Development Programme: Overview, 2004.

[62] J. Goldemberg, "Biomassa e Energia," Química Nova, Vol. 32, No. 3, 2009, pp. 582-587. doi:10.1590/S0100-40422009000300003

[63] Food and Agriculture Organization, "Agroenergia da Biomassa Residual: Perspectivas Energéticas, Socio- econômicas Ambientais,” Foz do Iguaçu/Brasília: Itaipu Binacional, Organização das Nações Unidas para a Agricultura e a Alimentação, 2009.

[64] Food and Agriculture Organization, "El Estado Mundial de la Agricultura y la Alimentación: Biocombustibles: Perspectivas, Riesgos y Oportunidades,” FAO, Roma, 2008. 